\title{
THEMATIC
}

Mental illness stigma research in Argentina

\author{
Martin Agrest, ${ }^{1}$ Franco Mascayano, ${ }^{2}$ Sara Elena Ardila-Gómez, ${ }^{3}$ Ariel \\ Abeldaño, ${ }^{4}$ Ruth Fernandez, ${ }^{5}$ Norma Geffner, ${ }^{6}$ Eduardo Adrian Leiderman, ${ }^{7}$ \\ Ezra S. Susser, ${ }^{8}$ Eliecer Valencia, ${ }^{9}$ Lawrence Hsin Yang, ${ }^{10}$ Virginia Zalazar $^{11}$ and \\ Gustavo Lipovetzky ${ }^{12}$
}

\begin{abstract}
Senior Researcher, Proyecto Suma, NGO, Buenos Aires,

Argentina, email magrest66@ gmail.com

${ }^{2}$ Associate Researcher, School of Public Health, Faculty of Medicine, University of Chile

${ }^{3}$ Postdoctoral Fellow, Scientific and Technical Research National Council (CONICET), Universidad Lanus, Buenos Aires, Argentina

4Postdoctoral Scholar, Scientific and Technical Research National Council of Argentina (CONICET), Counclic Council of Argentina (CONiCET), Faculty Medicine, Universidad Nacional de Cordoba, Argentina ${ }^{5}$ Professor, School of Public Health, Faculty of Medicine, Universidad Nacional de Universidad Naciona
Cordoba, Argentina ${ }^{6}$ Clinical Psychologist, Proyecto

Studies regarding stigma towards mental illness in Argentina blossomed after the first National Mental Health Law was passed in 2010. Methodological limitations and contradictory results regarding community perceptions of stigma hinder comparisons across domestic and international contexts but some lessons may still be gleaned. We examine this research and derive recommendations for future research and actions to reduce stigma. These include tackling culture-specific aspects of stigma, increasing education of the general population, making more community-based services available and exposing mental health professionals to people with mental illness who are on community paths to recovery.
\end{abstract} Suma, NGO, Buenos Aires, Argentina

${ }^{7}$ Associate Researcher, Proyecto Suma, NGO, Buenos Aires, Argentina

${ }^{8}$ Professor of Epidemiology and Psychiatry, Mailman School of Public Health Columbia

University, New York, USA

'Lecturer, Department of Epidemiology, Columbia

${ }^{10}$ Associate Professor Department of Epidemiology, Columbia University, New York,

${ }^{11}$ Research Fellow, Proyecto Suma, NGO, Buenos Aires, Argentina

${ }^{2}$ General Director, Proyecto Suma, NGO, Buenos Aires, Argentina

Conflict of interest statement: The authors declare that the research was conducted in the absence of any commercial or financial relationships that could be construed as a potential conflict of interest.

\section{conflict of interest.}

Acknowledgments: The research reported in this publication was supported by the Nationa institute of Mental Health under award U19MH095718, Proyecto Suma - NGO, and the National Council of Scientific and Technical Research of Argentina. The content is solely the responsibility of the authors.
Stigma is a well known obstacle in the recovery of people living with severe mental illness. Stereotypes, prejudice, discrimination and a desire for greater social distance are common among the general public, as well as among health and even mental health workers. Although stigma exists worldwide (and has done so throughout history), its effects vary, depending (as with all social processes) on the cultural context in which it appears. It affects coping strategies, disclosure and helpseeking, and has many other profound effects at the personal, familial and community levels (Mascayano et al, 2015). Examining stigma in local contexts in Argentina may lead to better research design and better national policies, and convey important lessons for other countries as well.

We make use of a recent historic transformation in Argentina - the 2010 National Mental Health Law - to examine ramifications of the new orientation towards providing mental health services in the community. We review research published after implementation of the law, examining articles addressing the stigma of mental illness in Argentina. We analyse the methods and outcomes reported in these articles to draw conclusions for future research and policy regarding the current transformation of the local mental health system.

\section{Stigma research in Argentina in context}

Argentina has recently been categorised as a high-income country. Of its population of some 42 million, less than $10 \%$ live in rural areas. Regarding mental healthcare, from 2001 to 2010, Argentina was gradually transitioning from hospital-based to community-based care. According to the National Health Department, the number of beds in public psychiatric hospitals dropped during those years by $51 \%$ (from 21000 to 10691 ), but still represented $89 \%$ of the total 11532 in-patient beds available for people with mental illness. That is, a mere $7 \%$ were located in general hospitals and $4 \%$ in community care centres (Dirección Nacional de Salud, 2010).

Accelerating this transformation to communitybased care was the enactment of a human rights-centred National Mental Health Law, passed in 2010, which fully adopts the social model of disability and follows the 2006 United Nations Convention on the Rights of Persons with Disabilities. The law explicitly grants protection from discrimination, despite not mentioning the term 'stigma', by declaring that 'everybody has the right not to be discriminated against because of a current or previous mental health condition'. Complementary to this statement, the more recent National Mental Health Plan (2013) declares that 'stigma is the first aim and problem to be addressed'.

Given this milestone, it is no wonder that there has been more research into stigma in the past 5 years than was done in the previous 45 years. Our focus in this paper is on how stigma has been investigated, and its implications for Argentina's ongoing transformation to community mental health.

\section{Research regarding stigma in Argentina since 2010}

A literature search was conducted using PubMed, PsycINFO Database, Scielo, Bireme and Lilacs, with the terms 'stigma', 'mental illness' and 'Argentina', for publications appearing up to April 2015. We narrowed the selection to empirical studies using quantitative or qualitative methods that focused explicitly on stigma towards mental illness, and found eight papers that were published after 2010 (Table 1).

Regarding methodology, all the quantitative studies were cross-sectional, mostly located in the Buenos Aires metropolitan area, and none of them recruited representative samples. Only one study solely used a qualitative approach and two others used mixed methods. These studies included a range of respondents: community members, service users, psychology and other students, 
Table 1

Overview of selected Argentinian studies of stigma

\begin{tabular}{|c|c|c|c|}
\hline Study & $\begin{array}{l}\text { Number in sample } \\
\text { (population sample was } \\
\text { drawn from) }\end{array}$ & Aims & Methods and instruments (quantitative or qualitative study) \\
\hline \multicolumn{4}{|l|}{ Public stigma } \\
\hline $\begin{array}{l}\text { Leiderman } \\
\text { et al (2011) }\end{array}$ & $\begin{array}{l}1254 \text { (members of the } \\
\text { general community } \\
\text { population) }\end{array}$ & $\begin{array}{l}\text { To assess the knowledge, social distance } \\
\text { and perception of social discrimination } \\
\text { towards persons with schizophrenia in the } \\
\text { general adult population of Buenos Aires, } \\
\text { Argentina }\end{array}$ & $\begin{array}{l}\text { Interviewer-assisted questionnaire divided into five sections (three of } \\
\text { them original); section } 4 \text { assessed social distance towards people with } \\
\text { schizophrenia with a modified version of the Bogardus Social Distance } \\
\text { Scale; section } 5 \text { addressed the perception of social stigmatisation through } \\
\text { Link's Discrimination-Devaluation scale. Convenience sampling was used. } \\
\text { (Quantitative) }\end{array}$ \\
\hline $\begin{array}{l}\text { Digiuni et al } \\
\text { (2013) }\end{array}$ & $\begin{array}{l}462 \text { (psychology degree } \\
\text { students in Argentina, the } \\
\text { UK and the USA) }\end{array}$ & $\begin{array}{l}\text { To examine the relationship between } \\
\text { clinical psychology students' perception } \\
\text { of the social stigma attached to receiving } \\
\text { therapy and their attitudes to seeking } \\
\text { therapy }\end{array}$ & $\begin{array}{l}\text { Students completed measures of demographic characteristics, the Attitudes } \\
\text { Toward Seeking Professional Psychological Help Scale - Short Form, and the } \\
\text { Social Stigma Scale for Receiving Psychological Help, and other variables } \\
\text { associated with therapy-seeking. (Quantitative) }\end{array}$ \\
\hline $\begin{array}{l}\text { Ardila- } \\
\text { Gómez et al } \\
\text { (2015) }\end{array}$ & $\begin{array}{l}236 \text { (neighbours and } \\
\text { equivalent non-neighbours } \\
\text { in the general population) }\end{array}$ & $\begin{array}{l}\text { To analyse the effects of community } \\
\text { life on people with mental illness in the } \\
\text { neighbourhoods in which they live, in } \\
\text { Buenos Aires, Argentina }\end{array}$ & $\begin{array}{l}\text { A non-standardised questionnaire blindly administered to randomly selected } \\
\text { neighbours }(n=117) \text { of group homes of a discharge programme and an } \\
\text { equivalent control area }(n=119) \text {. (Quantitative and qualitative) }\end{array}$ \\
\hline \multicolumn{4}{|c|}{ Consumer stigma } \\
\hline $\begin{array}{l}\text { Vazquez et } \\
\text { al (2011) }\end{array}$ & $\begin{array}{l}241 \text { (people with bipolar } \\
\text { disorder in Argentina, Brazil } \\
\text { and Colombia) }\end{array}$ & $\begin{array}{l}\text { To investigate the association between } \\
\text { self-rated stigma and functioning in } \\
\text { patients with bipolar disorder in Latin } \\
\text { America }\end{array}$ & $\begin{array}{l}\text { Functioning Assessment Short Test (FAST) and Inventory of Stigmatising } \\
\text { Experiences (ISE). (Quantitative) }\end{array}$ \\
\hline $\begin{array}{l}\text { Mileva et al } \\
\text { (2013) }\end{array}$ & $\begin{array}{l}392 \text { (people with bipolar } \\
\text { disorder in Argentina and } \\
\text { Canada) }\end{array}$ & $\begin{array}{l}\text { To adapt the Inventory of Stigmatizing } \\
\text { Experiences (ISE) and to evaluate its } \\
\text { basic psychometric properties among } \\
\text { Argentinian people with bipolar disorder }\end{array}$ & $\begin{array}{l}\text { The Stigma Experiences Scale (SES) and the Stigma Impact Scale (SIS) were } \\
\text { administered to patients with bipolar I and bipolar II disorder in Argentina } \\
(n=178) \text { and Canada }(n=214) \text {. (Quantitative) }\end{array}$ \\
\hline $\begin{array}{l}\text { Saldivia et } \\
\text { al (2014) }\end{array}$ & $\begin{array}{l}164 \text { (people with } \\
\text { schizophrenia and related } \\
\text { psychoses - service users) }\end{array}$ & $\begin{array}{l}\text { To develop a cross-cultural measure of } \\
\text { the stigma perceived by people with } \\
\text { schizophrenia }\end{array}$ & $\begin{array}{l}\text { Items for the scale were developed from qualitative group interviews with } \\
\text { people with schizophrenia in six countries ( } 18 \text { from Argentina). The scale was } \\
\text { then applied in face-to-face interviews. (Quantitative and qualitative) }\end{array}$ \\
\hline \multicolumn{4}{|c|}{ Institutional stigma } \\
\hline $\begin{array}{l}\text { Druetta et } \\
\text { al (2013) }\end{array}$ & $\begin{array}{l}517 \text { (mental health } \\
\text { practitioners) }\end{array}$ & $\begin{array}{l}\text { To determine general demographics, } \\
\text { attitudes and social distance of mental } \\
\text { health workers in relation to people with } \\
\text { schizophrenia }\end{array}$ & $\begin{array}{l}27 \text { questions in six sections; last section was an adaptation of Link's Social } \\
\text { Distance Scale. (Quantitative) }\end{array}$ \\
\hline $\begin{array}{l}\text { Wagner et } \\
\text { al (2011) }\end{array}$ & $\begin{array}{l}303 \text { (service users and } \\
\text { carers in Argentina, Brazil, } \\
\text { England, Chile, Venezuela, } \\
\text { Spain) }\end{array}$ & $\begin{array}{l}\text { To analyse the opinion of people with } \\
\text { schizophrenia in long-term care and their } \\
\text { (informal and formal) carers regarding } \\
\text { mental healthcare within different } \\
\text { contexts and cultures }\end{array}$ & $\begin{array}{l}\text { Eight focus groups were conducted in each country. The data were analysed } \\
\text { with the aid of the Qualitative Solutions and Research/Non-numerical } \\
\text { Unstructured Data Indexing program (QSR NUD*IST 4.0). (Qualitative) }\end{array}$ \\
\hline
\end{tabular}

carers and mental health practitioners. They addressed public stigma, perceived and self-stigma, and institutional or structural stigma. People with substance misuse disorders had not been targeted for research, despite some evidence that this group is the most stigmatised population (Ardila-Gómez et al, 2015).

Findings are organised in terms of their implications for implementation of community mental health services in Argentina.

\section{Public stigma}

The general population reported a low social distance from people with schizophrenia, with $80 \%$ of a local sample endorsing less than one-third of the maximum possible 'social distance' score. Still, one in four people surveyed declared that they would feel disturbed about working with a person with schizophrenia (Leiderman et al, 2011). People living in close proximity to former in-patients showed less discriminatory attitudes to people with mental illness than non-neighbours, thus suggesting that personal contact yields better acceptance of people with mental illness (Ardila-Gómez et al, 2015).
However, this finding was somewhat disputed by Leiderman et al, whose study showed that those who were familiar with people with schizophrenia did not show significantly less social distance than the general population. Overall, while there remains strong resistance to accepting people with mental illness, people may benefit from everyday contact with those with mental illness living in the community, as investigated in other contexts by Corrigan et al (2007).

\section{Consumer/self-stigma}

Regarding consumer/self-stigma, a mix of findings emerge. Self-stigma appears to lead to negative psychological outcomes, as an association was found between perceived stigma, social functioning and severity of affective symptoms (Vazquez et al, 2011), with stigma affecting quality of life and self-esteem (Mileva et al 2013).

With regard to characterising levels of selfstigma in Argentina, the results are contradictory. On the one hand, Digiuni et al found that Argentinian psychology students, compared with UK and US samples, would expect lower levels of perceived 
social stigma if they had received psychological treatment. Another study found that people with bipolar disorder reported fewer stigma experiences in Argentina than in Canada (Mileva et al, 2013). A third study reported that people with schizophrenia had few perceptions of discriminatory attitudes in custodial institutions (Wagner et $a l, 2011)$. However, another study found that people with schizophrenia in Argentina fared worst or near-worst on four dimensions of perceived stigma (informal networks, socio-institutional, health professional and self-stigma) in a comparison with five other countries (Saldivia et al, 2014). Thus, while the absolute level of self-stigma experienced in Argentina by varying types of consumers (except for those with schizophrenia) may be reported to be somewhat less than in other areas of the world, it is nevertheless associated with negative psychological outcomes - as in other countries.

\section{Institutional (or structural) stigma}

Mental health practitioners held significant discriminatory attitudes (Druetta et al, 2013; Saldivia et al, 2014) and those with more work experience showed greater social distance desire than younger ones. Thus, reducing stigma by providing more traditional clinical services would be ineffective in Argentina. Scarcity of community-based services was hypothesised to contribute to these more stigmatising attitudes among clinicians (Wagner et al, 2011; Saldivia et al, 2014).

\section{Conclusions}

As Argentina is moving towards community-based treatments, studies regarding stigma are proliferating and may help to overcome barriers in the full implementation of the National Mental Health Law. As an initial conclusion based on the above studies, while increased education efforts may help to reduce stigma in the general population, increased contact in collaborative situations that take place in the community rather than in clinical settings, in addition to interacting with consumers at different stages of recovery, might facilitate stigma reduction among practitioners.

Methodologically, most of the samples in the studies examined were non-representative in nature; moreover, the studies focused solely on attitudes. Emphasising the study of real-life experiences of discrimination (Thornicroft, 2006) and the use of representative population samples would increase confidence in research findings and provide a methodologically rigorous way to track stigma change as more community mental health services are implemented.

Another important gap we found is that the identification and measurement of culture-specific aspects of stigma are limited. Little information exists regarding how stigma is embodied in different Argentinian subgroups or locations distant from Buenos Aires, or regarding how important cultural values (e.g. strong family bonds) might protect people with mental illness in Argentina. These culture-specific aspects of stigma could be examined with systematic research using stigmaspecific frameworks (Mascayano et al, 2015).

It is our hope that a broad collaborative taskforce made up of academic researchers, mental health service staff, users, policy-makers, journalists and non-governmental organisations (NGOs) can bring forth new studies and a national campaign on stigma more sensitive to local idiosyncrasies, respectful of experiences from diverse perspectives and stakeholders, and grounded in the best empirical science.

\section{References}

Ardila-Gómez, S., Ares Lavalle, G., Fernandez, M., et al (2015) Social perceptions about community life with people with mental illness: study of a discharge program in Buenos Aires province, Argentina. Community Mental Health Journal, 51, 103-110.

Corrigan, P. W., Larson, J., Sells, M., et al (2007) Will filmed presentations of education and contact diminish mental illness stigma? Community Mental Health Journal, 43, 171-181.

Digiuni, M., Jones, F. W. \& Camic, P. M. (2013) Perceived social stigma and attitudes towards seeking therapy in training: a crossnational study. Psychotherapy, 50, 213-223.

Dirección Nacional de Salud (2010) Camas disponibles destinadas a la atención en Salud Mental y egresos hospitalarias del sector público en Argentina. (Sistema de Vigilancia Epidemiológica en Salud Mental y Adicciones 2.) [Available Beds for Mental Health Care and Hospital Expenses of the Public Sector in Argentina. (Epidemiological Surveillance System on Mental Health and Addiction 2.)] Dirección Nacional de Salud.

Druetta, I., Ceresa, F. \& Leiderman, E. (2013) Actitudes de los profesionales de la salud mental hacia las personas con esquizofrenia [Attitudes of mental health professionals towards people with schizophrenia]. Vertex, Revista Argentina de Psiquiatría, 24, 245-252.

Leiderman, E., Vazquez, G., Berizzo, C., et al (2011) Public knowledge, beliefs and attitudes towards patients with schizophrenia: Buenos Aires. Social Psychiatry and Psychiatric Epidemiology, 46, 281-290.

Mascayano, F., Armijo, J. E. \& Yang, L. H. (2015) Addressing stigma relating to mental illness in low- and middle-income countries. Frontiers in Psychiatry, 6, 38. doi: 10.3389/fpsyt.2015.00038.

Mileva, V., Vazquez, G. \& Milev, R. (2013) Effects, experiences, and impact of stigma on patients with bipolar disorder. Neuropsychiatric Disease and Treatment, 9, 31-40.

Saldivia, S., Runte-Geidel, A., Grandón, P., et al (2014) The Maristan Stigma Scale: a standardized international measure of the stigma of schizophrenia and other psychoses. BMC Psychiatry, 14, 182. doi: 10.1186/1471-244X-14-182.

Thornicroft, G. (2006) Shunned: Discrimination Against People With Mental Illness. Oxford University Press.

Vazquez, G., Kapczinski, F., Magalhaes, P. V., et al (2011) Stigma and functioning in patients with bipolar disorder. Journal of Affective Disorders, 130, 323-327.

Wagner, C. L., Runte-Geidel, A., Torres-González, F., et al (2011) Mental health care: perceptions of people with schizophrenia and their carers. Ciencia e Saude Coletiva, 16, 2077-2087.

\section{Royal College of Psychiatrists' International Congress 2016 27-30 June, London, UK}

1 December 2015: programme available online and registration opens

29 February 2016: early bird registration deadline Register your interest to keep up to date with the latest International Congress news. See http://www. rcpsych.ac.uk/traininpsychiatry/conferencestraining/ internationalcongress2016.aspx 